Original Article

\title{
BIOACTIVITY STUDY OF MOSS DUMORTIERA HIRSUTA (SWAEGR.) NEES ETHANOLIC EXTRACT ON PARASITEMIC LEVEL OF PLASMODIUM BERGHEI VINCKE AND LIPS, 1948 IN MICE (MUS MUSCULUS L.)
}

\author{
IMAM FATHONI ${ }^{*}$, S. HERRY POERWANTO ${ }^{2}$, R, R. UPIEK NGESTI WIBAWANING ASTUTI2
}

${ }^{1}$ Faculty of Biology, Gadjah Mada University, Yogyakarta, Indonesia, ${ }^{2}$ Laboratory of Parasitology, Faculty of Biology, Gadjah Mada University, Yogyakarta, Indonesia

Email: tonythoni@yahoo.com

Received: 06 Jun 2017 Revised and Accepted: 07 Jul 2017

\section{ABSTRACT}

Objective: Malaria is a major infectious disease in the world including Indonesia. The main problem in controlling malaria is its resistance by standard treatment. Dumortiera hirsuta has not been widely used by the public as an alternative medicine. Liverworts contain bioactive compounds such as flavonoids, terpenoids, and alkaloids one of which may reduce the level of Plasmodium in the blood.

Methods: Moss was collected from Telaga Putri waterfall, Yogyakarta. Samples were extracted by using 96\% ethanol. Thin layer chromatography (TLC) was used for detecting bioactive compounds. Peter's Suppressive Test method has been used for monitoring antiplasmodial activities of moss extract in male SWISS Strain mice. The $10^{7} \mathrm{P}$. berghei in $0.2 \mathrm{ml}$ of DMSO were infected intraperitoneally for the treated mice ( $\left.\mathrm{H}_{0}\right)$. There were 9 groups: 3 control groups, 1 placebo, and 5 treated groups on the $1^{\text {st }}$ day $\left(\mathrm{H}_{1}\right)$ until the $4^{\text {th }}$ day $\left(\mathrm{H}_{4}\right)$ D. hirsuta extract on $100 ; 200 ; 300 ; 400$ and 500 $\mathrm{mg} / \mathrm{Kg} \mathrm{BW}$ doses were given orally.

Results: The results of TLC showed that alkaloids, flavonoids, terpenoids, and saponins were detected in the extract of $D$. hirsuta. The most effective inhibition was showed at the dose $300 \mathrm{mg} / \mathrm{Kg} \mathrm{BW}$ up to $96 \%$, whether the control mice with chloroquine up to $77 \%$.

Conclusion: Ethanolic extract D. hirsuta could be potential source of an alternative antimalarial drug.

Keywords: Antimalaria, D. hirsuta, P. berghei

(C) 2017 The Authors. Published by Innovare Academic Sciences Pvt Ltd. This is an open access article under the CC BY license (http://creativecommons.org/licenses/by/4.0/) DOI: http://dx.doi.org/10.22159/ajpcr.2017v10s3.21349

\section{INTRODUCTION}

Malaria is a main parasitic disease in the world. This disease, which is caused by Plasmodium and transmitted by the Anopheles mosquito is main disease in more than 100 countries and about 2.4 billion people are endangered by this disease ( $40 \%$ of world population). Every 30 seconds a child dies from malaria. Approximately 3.3 billion people live in the potential area of malaria in 109 countries [1]. Malaria is the fifth infectious disease causing death after respiratory infections, HIV/AIDS, diarrhea, and TBC. Moreover, there are 247 million cases over the world and at least 1 million deaths caused by malaria until 2008. This disease mostly afflicts African countries and tropical areas. It is caused by the rapid growth of population combined with an imbalance of good sanitation. The high rate of malaria in a country causes a decline in economy up to 1.3 percent [2]

There has been an eradication program of malaria by the WHO since 1956 [3]. This effort has involved eradicating areas which can be used as a nesting place for the Anopheles mosquito, spraying, fogging, and providing cover to prevent a mosquito's bite. Mass treatment has also been done for malaria patients to prevent epidemic [4]. The first treatment of malaria was done by using tar from Chicona's rod which can repress Plasmodium's growth in the blood. In 1930, a German pharmacologist found Atabrine which is more effective than chicona and has less toxicity. Since World War II, chloroquine has been considered to be more capable in overcoming malaria and it is proven effective to overcome all kinds of malaria [5].

The existence of the Plasmodium strain which is resistant to medicines has caused malaria to spread further. Vectors which cause malaria, some kinds of Anopheles mosquitos are known to have resistance with insecticide so that the case number of malaria in some tropical countries increases. The available malaria medicines are usually synthetic and also can give side effect such as problems in vision, digestive problems and headaches [1]. These problems cause many researchers to try to discover new antimalarial compounds. One of the efforts is done by exploring mosses which are abundant in Indonesia. Moss is the oldest group of plants. The species of this moss consists of more than 24,000 in the world which are categorized into 3 classes. One of the reasons moss still exists until now is they contain bioactive compounds. Bioactive compounds which are contained inside are very interesting to explore because moss is avoided by other organisms as food resources [6].

Moss is known to have an important role for microorganisms. Moreover, moss has been used as a traditional medicine by society. It has been known that moss class Hepaticopsida contains lipophilic mono-, sesqui-, and diterpenoids, aromatic compounds and acetogenins which includes in oil bodies [6]. The other research also shows that moss from class Hepaticopsida, D. hirsuta, contains triterpenoids, flavonoids, and steroids. The compound from terpenoid group, alkaloid and flavonoid can inhibit the development of Plasmodium [7].

The moss $D$. hirsuta is ubiquitous in the high elevated areas in Indonesia, but until now this kind of moss has not been used. Based on that reason, there should be an exploration of bioactive compounds inside $D$. hirsuta and its potency as the alternative antimalarial in Indonesia.

\section{MATERIALS AND METHODS}

Preparation of extracts

The research started a collection sample of moss from Tlogo Putri water fall, Kaliurang, Sleman, Yogyakarta. The moss samples that were 
required then washed for eliminating re-substrate then dried for about 3 d. Afterwards, extraction was done with maceration method. The moss sample was cut up then submerged in ethanol $96 \%$ for about $24 \mathrm{~h}$, then filtered. The solvent of macerat was gathered. Parts of the extract was collected for Thin Layer Chromatography (TLC).

\section{Antimalarial bioassay}

This research used mice (Mus musculus L.) from the strain SWISS male. There were 27 mice at age 3 mo with an average weight of 30-35 grams. The mice were the product from Laboratorium Penelitian dan Pengujian Terpadu (LPPT) Unit III UGM (Research Center in Gadjah Mada University). Mice were treated with certain environmental conditions such as food, and drinking water which were qualitatively and quantitatively good. As many as 27 mice were divided into 9 groups, each group consisted of 3 mice. 4 groups were control groups and 5 groups were treatment groups. The mice were acclimated for about $3 \mathrm{~d}$ then given treatment for about $4 \mathrm{~d}$ based on Peter's Suppressive Test method [8]. The control of this research was done by giving chloroquine as many as $5 \mathrm{mg} / \mathrm{kg} \mathrm{BB} /$ day. The treatment concentration which were used: 100; 200; 300; 400 and $500 \mathrm{mg} / \mathrm{Kg} \mathrm{BB}$.

In the analysis of parasitemic level, mice were cut at the tail. The blood was dropped on the glass object and was smeared thinly. Afterwards, the glass containing the blood was fixated with methanol for 3-5 min, then colored by Giemsha 5\%, dried for $30 \mathrm{~min}$, then washed with flow water and dried at a normal temperature. The result of staining was then photographed under a camera which is integrated with a microscope with $40 \times 10$ magnification.

The results of the research were then analyzed using Microsoft Excel to get the inhibition value of extract against Plasmodium. The result of the research was then analyzed using one way ANOVA and DMRT with SPSS program version 16.0 and presented in the sketch of average deviation standard Result of TLC was compared with original compounds, which are an alkaloid, terpenoid, flavonoid, and saponin.

\section{RESULTS AND DISCUSSION}

Moss has widely been used as traditional medicine in some areas, such as in the remote area in India [9]. Moss of hepaticopsida class (heart moss) is known to contain lipophilic mono, sesqui, and diterpenoids, aromatic compounds, and acetogenins which are included in oil bodies. The research of [1], shows that moss of class Hepaticopsida, D. hirsuta contains triterpenoid, flavonoid, and steroid. So far, using of moss $D$. hirsuta fig. 1 still has not been done yet. But, some research shows that moss of Hepaticopsida can be used as herbal medicine for hepatitis, and heal poison from snake bites is antipyretic, antidotal, has a diuretic activity, and is used for the treatment of external injuries [6].

According to [7], bioactive compounds such as alkaloid, flavonoid, terpenoid, and saponin can work together to inhibit the development of Plasmodium by disturbing the process of its membrane synthesis. The compound will also bound with the component of Plasmodium membrane which it causes failure in self-replication.

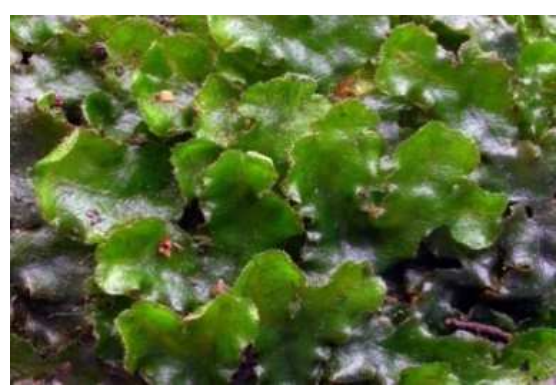

Fig. 1: Dumortiera hirsuta [10]

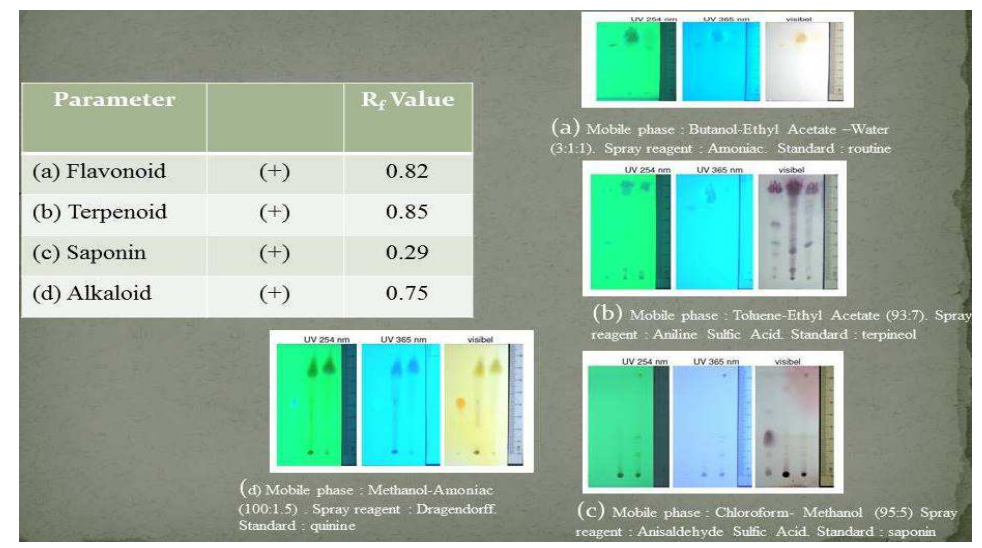

Fig. 2: The result of thin layer chromatography (TLC) analysis

Fig. 2 shows the result of thin layer chromatography. It shows that there are bioactive compounds inside $D$. hirsuta. The test result of bioactive compounds with TLC method shows that there are alkaloids, flavonoids, terpenoids, and saponins which are showed by spots which are formed on the plate in each analysis of the compounds. This TLC result matches with previous research which notes that those group compounds can be found in the Marchantia sp. which is in the same class as Dumortiera.

According to [11], quinine, one of the first to be discovered of antimalarial compounds is from an alkaloid group. According to the research of [7], many kinds of alkaloids have antimalarial activity, one of which is the cassiarin alkaloid from Cassia leave extract against $P$. falciparum. The other alkaloids, harmine and harmaline show moderate antimalarial activity against $P$. falciparum. Quinine has the ability to inhibit the growth of merozoite phase of Plasmodium in blood. The research of [12] tells that alkaloid compounds can prevent parasite polymerization when hemoglobin degradation occurs so that a parasite's cell membrane breaks and its growth is disturbed.

Flavonoid compounds are very abundant in plants and can be isolated from many kinds of plants. One of the examples is flavonoid from fraction 147 and 148 which were isolated from Neoraputia magnifica (Rutaceae). According to the research of [7], those flavonoids with flavonoid fraction 149 isolated from Lonchocarpus subglaucescens (Leguminosae) show antiplasmodial effect to $P$. falciparum. The other flavonoids, flavone 3-methoxycarpachromene which was isolated from Pistacia atlantica also shows antimalarial activity against $P$. falciparum.

Terpenoid compounds are isolated much from plants and have been used for antimalarial, such as artemicine from Artemisia annua as antimalarial since 2000 y ago in China. The mechanism of terpenoid compounds inside $D$. hirsuta is probably similar to artemicines. This happens because artemicine is the sesquiterpene which includes in 
the terpenoids group. Sesquiterpene consists of three isoprene units. The structure of a peroxide bridge in sesquiterpene is cut by ion $\mathrm{Fe}_{2}+$ from heme and changes into free radicals. The free radicals can settle the position between nitrogen bases from parasite's DNA. The conformation of a gene code will change and ruin genetic information in the DNA template of Plasmodium. Synthesis of DNA in the parasite will be disturbed so that the parasite is hindered in its development and growth [6].

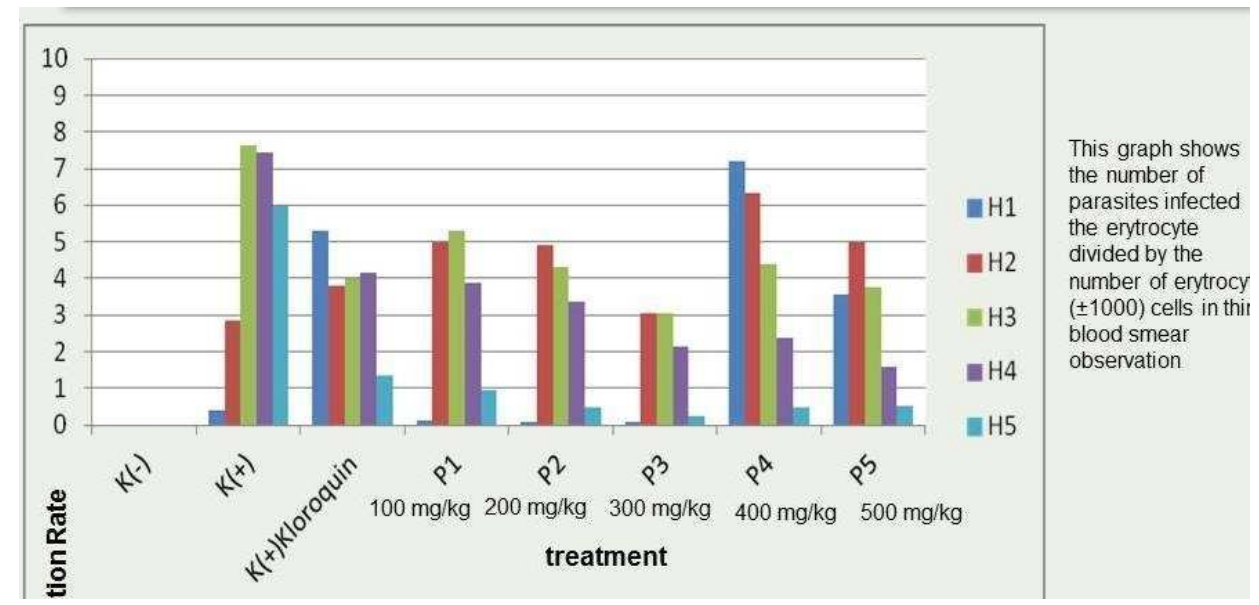

Fig. 3: The variation of parasitemic levels of P. berghei from H1 (day 1) to H5 (day 5)

Based on fig. 3, the variation of parasitemic levels of $P$. berghei inside mice from the first day until fifth-day observation can be seen. The most significant decline is seen in P3 treatment group $(300 \mathrm{mg} / \mathrm{Kg}$ $\mathrm{BB}$ ) in the fifth day which is looked as the lowest level compared with others. Overall, the declination of the parasitemic level by $D$. hirsuta extract treatment is better than positive control given with chloroquine. This is caused by the existence of bioactive compounds, alkaloids, flavonoids, terpenoids, and saponins in the extract which can prohibit the growth rate of $P$. berghei in the mice. Ethanolic extract of $D$. hirsuta has a tendency to reduce parasitemic levels, but in each concentration of treatment each day an observation in reprising parasitemic level must be seen.

Table 1: The inhibition percentage of $P$. berghei's growth by chloroquine and $D$. hirsuta ethanolic extract

\begin{tabular}{lllll}
\hline Group & $\mathbf{1}^{\text {st }} \mathbf{D}$ & $\mathbf{2}^{\text {st }} \mathbf{D}$ & $\mathbf{3}^{\text {st }} \mathbf{D}$ & $\mathbf{5}^{\text {st }} \mathbf{D}$ \\
\hline K(+) Chloroquine & -12 & -34 & 48 & 74 \\
P1(100 mg/kg BB) & 68 & -75 & 31 & 48 \\
P2(200 mg/kg BB) & 81 & -73 & 44 & 54 \\
P3(300 mg/kg BB) & 77 & -8 & 6 & 71 \\
P4(400 mg/kg BB) & -17 & -1 & 43 & 98 \\
P5(500 mg/kg BB) & -8 & -75 & 51 & 96 \\
\hline
\end{tabular}

Inhibition percentage: $\frac{\Sigma \text { parasite in } \mathrm{K}(+)-\Sigma \text { parasite in treatment }}{\Sigma \text { parasite in } \mathrm{K}(+)} \times 100 \%$

The result showed from table 1 indicates that there is a similarity in effectivity between $D$. hirsuta ethanolic extract to the standard medicine of malaria, chloroquine. Furthermore, all the treatment showed a bigger decrease in parasitemic level than chloroquine.
Table 2 shows the statistical analysis result by using software SPSS 16.0. The results of statistical analysis $(\mathrm{p}<0.05)$ show that there is a clear significance between control (+) without chloroquine, control+with chloroquine, and D. hirsuta extract in the third-day observation. In the fifth day, control+group shows significant differences with control+group which is treated with chloroquine and all treatment groups.

Table 2: The result of statistical analysis by using SPSS 16.0

\begin{tabular}{|c|c|c|c|c|c|}
\hline \multirow[t]{2}{*}{ Group } & \multicolumn{5}{|c|}{ Day observation } \\
\hline & 1 & 2 & 3 & 4 & 5 \\
\hline $\mathrm{K}(-)$ extract & 0 & 0 & 0 & 0 & 0 \\
\hline $\mathrm{K}(-)$ placebo & 0 & 0 & 0 & 0 & 0 \\
\hline$K(+)$ & $0.39 \pm 0.39$ (a) & $2.84 \pm 3.45^{(\mathrm{a})}$ & $7.64 \pm 0.43^{(\mathrm{a})}$ & $7.44 \pm 0.23^{(\mathrm{a})}$ & $5.97 \pm 1.37$ (a) \\
\hline $\mathrm{K}(+)$ Chloroquine & $5.28 \pm 5.28^{(a, b)}$ & $3.81 \pm 1.15^{(a)}$ & $3.99 \pm 0.37^{(a, b)}$ & $4.16 \pm 0.42^{(a)}$ & $1.35 \pm 1.35^{(a)}$ \\
\hline P1(100 mg/kg BB) & $2.12 \pm 0.04^{(\mathrm{a})}$ & $4.96 \pm 3.25^{(a)}$ & $5.31 \pm 2.34(\mathrm{a})$ & $3.88 \pm 0.52^{(a)}$ & $0.96 \pm 0.21^{(a)}$ \\
\hline P1(100 mg/kg BB) & $0.07 \pm 0.01^{(\mathrm{a})}$ & $4.89 \pm 0.51^{(\mathrm{a})}$ & $4.28 \pm 1.96^{(a, b)}$ & $3.37 \pm 0.96^{(a, b)}$ & $0.47 \pm 0.25^{(a)}$ \\
\hline P1(100 mg/kg BB) & $0.09 \pm 0.003^{\text {(a) }}$ & $3.05 \pm 1.38^{(a)}$ & $3.05 \pm 0.07$ (a) & $2.14 \pm 0.35^{(\mathrm{a})}$ & $0.24 \pm 0.19$ (a) \\
\hline P1(100 mg/kg BB) & $7.19 \pm 1.8^{(a)}$ & $6.33 \pm 0.64{ }^{(a)}$ & $4.37 \pm 1.24^{(a, b)}$ & $2.37 \pm 0.19^{(a, b)}$ & $0.49 \pm 0.36^{(a)}$ \\
\hline $\mathrm{P} 1(100 \mathrm{mg} / \mathrm{kg} \mathrm{BB})$ & $3.54 \pm 0.82^{(a)}$ & $4.97 \pm 2.85^{(a)}$ & $3.76 \pm 1.08^{(a, b)}$ & $1.57 \pm 0.56^{(\mathrm{a})}$ & $0.51 \pm 0.30^{(a)}$ \\
\hline
\end{tabular}

Note: Number followed by the same alphabet in the same column shows no significant difference (a-b)

Chloroquine is the most important medicine in malaria treatment because it works quickly, effectively, and has less side effects. According to [4], the mechanism of this medicine is suspected to be connected with nuclei acid synthesis and nucleoprotein by preventing DNA polymerase and RNA polymerase which gives the effect of stability in DNA complex of parasite so that the DNA synthesis of the parasite is disturbed. 


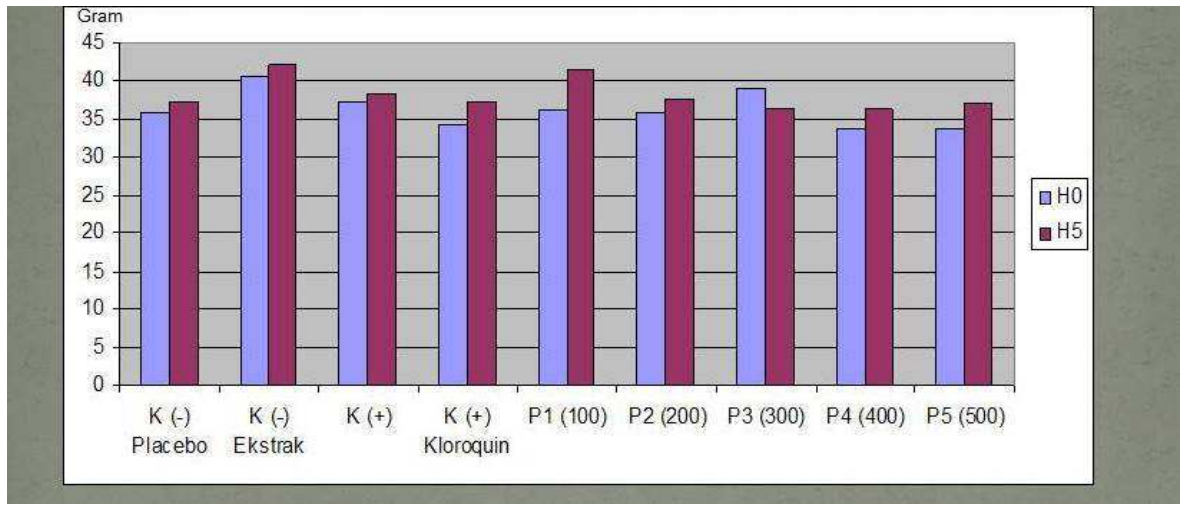

Fig. 4: The average weight of mice before and after treatment $(\mathrm{HO}=$ before treatment, $\mathrm{H} 5=$ after treatment $)$

The tendency of the increase and decrease of weight before and after treatment can be an indicator of the side effects of the extract treatment physiological effect of mice. The description about the change in weight in each treatment can be seen in fig. 4. Based on fig. 4 , it can be seen that there are variations of mice's weight after and before treatment in each treatment group. The average weight of mice before treatment is about 30-40 gram, and after treatment is 35-42 gram. The weight of mice does not change and tend to increase in all treatments. This indicated that there was no side effect in the physiological response of mice. The macroscopic observation of mice's spleen, kidney, and heart showed that there is no significance change which means there is no damage in mice's organs. However, microscopic observation should be done to know further about the damage in mice's organs.

\section{CONCLUSION}

The ethanolic extract of D. hirsuta contains alkaloids, flavonoids, terpenoids, and saponins. The most effective inhibition to P. berghei was showed at the dose $300 \mathrm{mg} / \mathrm{Kg}$ BW up to $96 \%$, whether the control mice with chloroquine up to $77 \%$. Ethanolic extract $D$. hirsuta could be a potential source of an alternative antimalarial drug.

\section{ACKNOWLEDGMENT}

The authors wish to thank to Laboratory of Parasitology, Faculty of Medicine, Gadjah Mada University for providing the Plasmodium berghei and Laboratory of Parasitology, Faculty of Biology, Gadjah Mada University for providing laboratory equipment for conducting this research. We also wish to thank Dr. Joseph Karuzis of Hokkaido University for his assistance and helpful comments.

\section{CONFLICT OF INTERESTS}

Declared none

\section{REFERENCES}

1. CDC. Malaria; 2012. Available from: http://www.cdc.gov/ malaria/. [Last accessed on 02 Jan 2016]

2. Gandahusada S, Herry DI, W Pribadi. Medical Parasitology Third Edition. Faculty of Medicine, University of Indonesia: Jakarta; 1998.

3. CDC. CDC and Malari; 2014. Available from: http://www.cdc.gov/malaria/. [Last accessed on 02 Jan 2016]

4. Levine ND. Protozoologi Veteriner. Translated by: Soeprapto Soekardono dan Muhayat D. Brotowidjodjo. Gadjah Mada University Press. Yogyakarta; 1995.

5. Asakawa Y. Biologically active compound from bryophytes. Pure Appl Chem 2007;79:557-80.

6. Nogueira CR, LMX Lopes. Antiplasmodial natural products. Molecules 2011;16:2146-90.

7. Peter Y. Technique for the study of drug response in experimental malaria chemotherapy and drug resistance in malaria. New York: Academic Press; 1970.

8. Akiyama H, T Matsuoka, T Yamaguchi. Biosystematics study of dumortiera hirsuta complex, monoploid and diploid diversification in the hawaiaan island. Polish Bot J 2012;57:81-93.

9. Rumsey L. D. hirsuta; 2012. Available from: http://bryophytes.plant.siu.edu/im [Last accessed on 02 Jan 2016]

10. Lohombo-Ekomba. Antibacterial, antifungal, antiplasmodial and cytotoxic activities of Albertisia villosa. J Ethnopharm 2004;93:331-5.

11. Sabovlejic MT Cvetic, V Stevanovic. Bio-activities of extract from some axenically farmed and naturally grown bryophytes. J Med Plants Res 2010;5:565-71. 